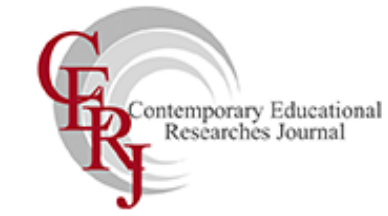

www.cerj.eu

\title{
Issues concerning Romanian demographic school population
}

Elena Pet, University of Agricultural Sciences and Veterinary Medicine from Timisoara, Timisoara, Romania Ioana Anda Milin*, University of Agricultural Sciences and Veterinary Medicine from Timisoara, Timisoara, Romania

Iuliana loana Merce, University of Agricultural Sciences and Veterinary Medicine from Timisoara, Timisoara, Romania

Ioan Brad, University of Agricultural Sciences and Veterinary Medicine from Timisoara, Timisoara, Romania

Cornelia Petroman, University of Agricultural Sciences and Veterinary Medicine from Timisoara, Timisoara, Romania

\section{Suggested Citation:}

Pet, E. Milin, I. A., Merce, I. I., Brad, I. \& Petroman, C. (2021). Issues concerning Romanian demographic school population. Contemporary Educational Researches Journal. 11(1), 18-26.

https://doi.org/10.18844/ceri.v11i1.4730

Received October 20, 2020; revised December 20, 2020; accepted February 02, 2021.

Selection and peer-review under responsibility of Assoc. Prof. Dr. Deniz Ozcan, Ondokuz Mayıs University, Turkey.

(C2021 Birlesik Dunya Yenilik Arastirma ve Yayincilik Merkezi. All rights reserved.

\section{Abstract}

The evolution of demographic phenomena of the last two decades is characterised by the need to maintain low fertility, the slight increase in life expectancy at birth, high percentage of infant mortality and negative balance of external migration, all of which have led to the decrease in the population of our country Romania. Between the two censuses (2002 and 2011), Romania's stable population decreased by 1.6 million. The population of students in all levels of the educational system has been reduced as a result. This paper analyses the main demographic issues facing Romania, its effect on the current school population and its long-term perspective. Using quantitative data that were derived from certified institutions and national documents, this study made a review of the literature of student population between the years 2002 and 2011 and a forecast for the following decades. One of the findings is that there is an increase in the ageing population. Recommendations are made at the end of the study.

Keywords: Demography, education, school age.

\footnotetext{
* ADDRESS FOR CORRESPONDENCE: Ioana Anda Milin, University of Agricultural Sciences and Veterinary Medicine from Timisoara, Romania. E-mail address: anda milin@yahoo.com
} 


\section{Introduction}

The population of a country is essential for its growth (Acemoglu, Fergusson \& Johnson, 2020). This is evident in certain countries such as China and Japan, whose population is a multiple of most country's population (Li, Lei, Wu, He, Chen \& Yan, 2017; Luo, Zhang, Wu, Shen, Shen \& Xing, 2018). Most countries boast of their economic benefits, as well as the growth in psychological health and security, they enjoy as a result of their population size (Mohammadi Laini \& Gholami, 2015). However, there are negative sides to large population sizes, such as environment problems, health and risk factors, as well as imbalances in the distribution of wealth in the citizens (Acemoglu et al., 2020; Luo et al., 2018; Park, 2020). Irrespective of the shortfalls of having a large population, the benefits still outweigh the blights of a larger population (Coale \& Hoover, 2015; Luo et al., 2018).

Several researchers have examined the decrease in population over the last two decades. For instance, in Iran, Mehrolhassani, Mirzaei, Poorhoseini and Oroomiei (2019) studied the reasons for the decrease in population over the years. According to the research, Mehrolhassani et al. (2019) attributed the fall in population to a decrease in fertility rate, structural imbalances, social planning and population control. The fertility rate in Iran as of 2011 was 1.6 children, as compared to 6.5 children in 1970 (Mehrolhassani et al., 2019). A similar research was conducted in the United States by Tannus and Dahan (2019) and Aksoy and Yilmaz (2019). In the research, Tannus and Dahan (2019) explained that the decrease in population growth in the United States was a result of infertility in males and a delay in childbirth by women. In Bulgaria, Shopov, Mihaylova and Stoeva (2016) also studied the birth rate, the demography and the abortion rate among women among the top causes of population decrease in the country. Other researches have examined this phenomenon in other locations as well.

Romania is one of the countries that is facing a sharp decline in its population (Dobos, 2020; Mirela, Nicu \& Oana-Valentina, 2016). The size of the drop is unexpectedly high, and it is especially the contribution that has had external migration, highlighted the demographic decline, amplifying an imbalance, particularly in light of the age structure of the population as present in other countries (Ahmed, Djelti \& Guellil, 2020; Karaca, Uzun, Metin, Sermin \& Aral, 2020). Resident population of school age from 0 to 23 years represent the main segment of children and young people enrolled in the education system, starting with primary school up to university, doctoral and postdoctoral programs. As of 1 January 2015, Romania's school age population (0-23 years) was 5.0438 million people, with 328,700 people less than in 2011 (National Institute of Statistics-Population Census, 1992-2011; National de Statistica, 2013). According to census data, between 2002 and 2011 the total population was reduced by $7.2 \%$ which means there was a decrease in about 1.6 million people. The demographic decline was produced at an average annual rate of $0.76 \%$. Registered stable population census in October 2011 was 20.1216 million inhabitants, of which 9.7886 million were men (48.6\%) and $10,333.0$ thousand were women $(51.4 \%)$.

As previous literature already explained, the population of a country has an adverse effect on various sectors and aspects of that economy (Saricam \& Ozbey, 2019). As projected by the National institute of Statistics in Romania, there is a decline in students over the years in various levels of the educational system as a result of population decrease. Several researches have studied population decrease or increase in various parts of the world. Researches with regard to student population are, however, limited (Dax \& Fischer, 2018; Fihel \& Okolski, 2019; Cheah, Feng, Tang, Lim \& Halliwell, 2016). This research, therefore, intends to initiate a debate on population decrease and its consequence on the reduction in student population. The aim of this research is to analyze the main demographic issues facing Romania, its effect on the current school population and its long-term perspective. The following research questions guided this research:

RQ1: Why does the trend of population decrease over the years?

RQ2: What is the composition of the various age groups? 
RQ3: What is the forecast for the population in upcoming years?

RQ4: What are the effects of the gradual reduction of population on the forecast of population of students?

\section{Methodology}

The research design of this study is a review of the literature. The review, however, is of national documents and archives, coupled with a few academic research works. This research used quantitative data that were collected from the upstream of Romania with a search of the archives through their website (https://insse.ro/cms/en). The National Institute of Statistics was one of the vital sources of information for this research. The National Institute of Statistics, which is a certified government institute in Romania, is tasked with all issues related to statistics. They are in charge of collating economic statistics, geographical statistics, population census and they are also tasked with the responsibility of making forecast to enable the government make informed decisions that require statistical information. The data from the National Institute of statistics are therefore reliable and valid. The Ministry of Education and Research of Romania also provided insight on various aspects of the Romanian education sector that needs to be addressed.

This research first of all started with the literature review of previous studies, which gave the researcher an insight of what previous researchers had studied with regard to population decrease and student demographics. The next step was to obtain the information from the National Institute of Statistics. The researchers in order to make a good analysis collated census results from the years 1992, 2002 and 2011. The age demographics of the population was also taken into account. There was also a need to collect information about forecast in order to complete this research's analysis. In totality, the data used for this research covered the years between 1992 and 2015.

\section{Findings}

The following section gives details of the findings of this research.

\subsection{Romanian population census}

Table 1. Romanian population census (in thousands)

\begin{tabular}{cccccc}
\hline Years & Total & Male & Female & Urban & Rural \\
\hline 1992 & $22,810.0$ & $11,213.7$ & $11,596.3$ & $12,391.8$ & $10,418.2$ \\
2002 & $21,681.0$ & $10,568.8$ & $11,112.2$ & $11,435.1$ & $10,245.9$ \\
2011 & $20,121.6$ & $9,788.6$ & $10,333.0$ & $10,858.8$ & $9,262.8$ \\
\hline
\end{tabular}

National Institute of Statistics-population census (1992-2011).

Comparing census data from 2011 with data obtained from the censuses of 2002 and 1992, the result was that the population of Romania and structure of the demographic developments, trends and novel mutations were different from those reported in previous decades, which we used.

The causes of population decline are a direct result of the trends in the demographic phenomena: birth rate, mortality and external migration. Thus, the following were discovered to contribute to the decline:

- Low fertility (1.46 children/woman) does not ensure generational replacement, it should be at least 2.1 children/woman. The evolution of fertility is affected, in addition to demographic factors and some behaviour changes in the number and structure of fertile female contingent. Factors for decrease in birth are multiple: women's empowerment and participation of its growing economic activities outside the household, increasing duration and level of education, weakening the influence of cultural norms, social mobility increasing high cost of child 
reducing economic function of child and especially its role in the economic security of older people, the emergence of modern contraceptive etc. (Mihaescu, 2020).

- At EU 28 population growth in recent years was due to net migration rates high and Romanians are considered the most mobile, followed by Polish and German; external migration of Romanians are elevated but not quantified exactly, especially if temporary labour migration, of those who are working, 65\% are aged between 20 and 40 years, so they are from being active in terms of procreation,

- Total mortality of population movements - compact recalculated based on the population stable in October 2011 was increased to 12.5 deaths per 1,000 inhabitants.

According to Eurostat estimates, if the current demographic decline continues, Romania's population will decrease to 19.8 million people (7.5\%) by 2035, from 21.4 million as recorded in early 2010, and then reduce by 2060 to 17.3 million people, which is the fourth drop in the European area after that recorded in Bulgaria $(-15.3 \%)$, Latvia $(-12.7 \%)$ and Lithuania $(-10.6 \%)$. The age pyramid of 2011 indicates that, in terms of age, the population of Romania is as follows: 15\% population are between 0 and 14 years, $70 \%$ are between 15 and 64 years and 15\% are over 65 years. Persons aged 85 years and over were, in October 2011, 1.3\% of the population and stable. Ageing index representing the number of elderly people per 100 children was 102 in 2011 compared to 80 in 2002.

Table 2. Elderly population (\%)

\begin{tabular}{llllll}
\hline \multicolumn{1}{c}{ Year } & $\mathbf{2 0 0 2}$ & $\mathbf{2 0 0 7}$ & $\mathbf{2 0 1 1}$ & $\mathbf{2 0 1 2}$ & $\mathbf{2 0 1 5}$ \\
\hline $\begin{array}{l}\text { The share elderly/total (\%) } \\
\begin{array}{l}\text { The share of elderly } \\
\text { population/area (\%) }\end{array}\end{array}$ & 19.22 & 19.36 & 20.49 & 20.83 & 21.17 \\
\hline Adapted from National de Statistica (2013). & 23.79 & 23.98 & 24.02 & 24.06 \\
\hline
\end{tabular}

\subsection{Romania's population forecasts}

The analysis of demographic evolution in the period 1992-2011 and beyond was the basis of design scenarios under which the anticipation level of fertility, life expectancy at birth and migration growth will be registered in Romania until 2060. Future developments in Romania's population is shown in Table 3:

Table 3. Romania's population forecasts

\begin{tabular}{lccccc}
\hline Variant & 2011 & $\mathbf{2 0 3 0}$ & $\mathbf{2 0 6 0}$ & $\begin{array}{c}\text { Absolute } \\
\text { thousands } \\
\text { pers. }\end{array}$ & $\begin{array}{c}\text { Relative } \\
\%\end{array}$ \\
\hline Constant & $20,121.6$ & $18,047.0$ & $12,946.7$ & $-7,174.9$ & -35.7 \\
Optimistic & $18,270.3$ & $13,966.8$ & $-6,154.8$ & -30.6 \\
Pessimist & $17,777.6$ & $11,926.4$ & $-8,195.2$ & -40.7 \\
Constant & $20,121.6$ & $18,121.9$ & $13,232.7$ & $-6,889.0$ & -34.2 \\
Optimistic & Without external migration & -29.1 \\
Pessimist & $18,346.1$ & $14,270.5$ & $-5,851.2$ & -39.4 \\
\hline
\end{tabular}

Adapted from National de Statistica (2013).

It is to be noted that all design choices, both versions with external migration and variation without external migration, will have a decrease in the population, ranging between 5.9 million and 8 million people. According to the National Institute of Statistics in Romania, it is expected that the population will continue to decline through 2060 to approximately 7.2 million people (in the version with external migration) or about 6.9 million people (in the version without external migration) (Garcia, Toledo \& Rodriguez, 2020; loana, Anda, Cornelia \& Mariana, 2015). 
Continuing the values declining birth and fertility, and with age generations, different in size, structure by large age groups of the population will continue to change in order to reduce the number and proportion of young people and increase the number and adult and elderly population share. The share of elderly in the total population will increase during $2011-2060$ from $16.1 \%$ to over $26.0 \%$, and the proportion of young people will decrease from $15.9 \%$ to over $12.0 \%$, which will lead to increased degree of demographic ageing of the Romanian population. Total demographic dependency ratio will gradually increase from 47 (2011) to 63 young and elderly per 100 adults (2060).

On school population and improving educational programs, the development strategy of this segment is part of the Europe 2020 Strategy (Iudici, Laura, Faccio \& Neri, 2020; Ministry of Education and Research, 2016). Europe 2020 Strategy has the following key objectives for the decade 2010-2020 related to education

(a) increasing the rate of occupation of the population aged between 20 and 64 years of age less than $75 \%$

(b) the $3 \%$ of GDP on R \& D.

(c) reducing the early school leaving a maximum of $10 \%$ and increasing the percentage of individuals aged 30 and 34 years with tertiary degree to at least $40 \%$ in 2020 .

The national education system comprises the following levels:

(a) early education, 0-6 years, formed the ante, pre-school 0-3 years and 3-6 years, including small group, middle group and large group.

(b) primary, comprising the preparatory class and classes I-IV.

(c) secondary, comprising secondary or secondary lower and upper secondary which may be highschool education and professional education for a minimum period of 3 years.

Id) non-university tertiary comprising high school education.

(e) university education, on three levels: undergraduate, master, doctorate.

Strategic targets [4] for 2020 were as follows:

- $\quad$ at least $15 \%$ of adults should participate in programs of lifelong learning.

- the percentage of 30-34 years who have completed tertiary education should be at least $40 \%$.

- proportion of early school leaving from education and training should be less than $10 \%$.

- at least $95 \%$ of children aged 4 years and the age for starting compulsory primary education should receive preschool.

- $\quad$ proportion of employed graduates aged 20-34 who have completed vocational education and training no more than 3 years before the reference year should be at least $82 \%$, compared to $76.5 \%$ in 2010 .

Although the country of Romania's Education Ministry along with other government institutions are striving to put in measures to control the school demographic, there are still directional problems that need to be addressed. For instance, the school population is progressively decreasing. As we said in the school age group people enrol those between 0 and 23 and over. Statistical data forecast shows important changes that will occur in the development of specific segments of the population: preschool population (3-6 years) and school age (7-14 years and 15-24 years) until 2060. 


\subsection{Forecast of the Romanian population by age group}

Table 4. Forecast of the Romanian population by age group

\begin{tabular}{|c|c|c|c|c|c|c|}
\hline & \multicolumn{2}{|l|}{2011} & \multicolumn{2}{|c|}{2030} & \multicolumn{2}{|c|}{2060} \\
\hline & $\begin{array}{c}\text { Thousands } \\
\text { pers. }\end{array}$ & $\%$ & $\begin{array}{c}\text { Thousands } \\
\text { pers }\end{array}$ & $\%$ & $\begin{array}{c}\text { Thousands } \\
\text { pers. }\end{array}$ & $\%$ \\
\hline \multicolumn{7}{|c|}{ With external migration } \\
\hline Total & $20,121.6$ & 100.0 & $18,047.0$ & 100.0 & $12,946.7$ & 100.0 \\
\hline $0-14$ & $3,189.6$ & 15.9 & $2,397.6$ & 13.3 & $1,567.8$ & 12.1 \\
\hline $15-64$ & $13,684.3$ & 68.0 & $12,099.1$ & 67.0 & $7,921.9$ & 61.2 \\
\hline over 65 & $3,247.7$ & 16.1 & $3,550.3$ & 19.7 & $3,457.0$ & 26.7 \\
\hline \multicolumn{7}{|c|}{ Without external migration } \\
\hline Total & $20,121.6$ & 100.0 & $18,121.9$ & 100.0 & $13,232.7$ & 100.0 \\
\hline $0-14$ & $3,189.6$ & 15.9 & $2,441.0$ & 13.5 & $1,659.4$ & 12.5 \\
\hline $15-64$ & $13,684.3$ & 68.0 & $12,131.5$ & 66.9 & $8,116.1$ & 61.3 \\
\hline Over 65 & $3,247.7$ & 16.1 & $3,549.4$ & 19.6 & $3,457.2$ & 26.2 \\
\hline
\end{tabular}

Compared with 2011, the number of children of 3-6 years will fall by nearly half in 2060 . Their number will be just over 403,000 people under the condition that there is external migration and 423,000 people under the condition where there is no external migration.

\subsection{Projected school population}

Table 5. Projected school population

\begin{tabular}{lccccc}
\hline & $\mathbf{2 0 1 1}$ & \multicolumn{2}{c}{ Thousands pers } \\
& $\mathbf{2 0 3 0}$ & $\mathbf{2 0 6 0}$ & \multicolumn{2}{c}{$\begin{array}{c}\mathbf{2 0 6 0 / 2 0 1 1} \\
\text { Absolut } \\
\text { (Thousand pers) }\end{array}$} & $\begin{array}{c}\text { Relative } \\
\text { \% }\end{array}$ \\
\hline Group 3-6 years & 850.6 & With external migration \\
Group 7-14 years & $1,723.4$ & 615.8 & 403.7 & -446.9 & -52.5 \\
Group 15-24 years & $2,700.7$ & $1,335.4$ & 872.5 & -850.9 & -49.4 \\
& \multicolumn{2}{c}{ 2,151.0 } & With external migration & -1333.9 & -49.4 \\
Group 3-6 years & 850.6 & 627.1 & 427.5 & -123.1 & -49.7 \\
Group 7-14 years & $1,723.4$ & $1,360.3$ & 924.0 & -799.4 & -46.4 \\
Group 15-24 years & $2,700.7$ & $2,185.3$ & $1,441.9$ & $-1,258.8$ & -46.6 \\
\hline
\end{tabular}

Adapted from National de Statistica (2013).

Between 2011 and 2060, the population of compulsory school age (7-14 years) will decrease by more than 850,000 people. Under the condition that people do not migrate, the population of students would decrease by 873,000 people and under the condition that there is migration, student population would decrease by 924,000 people.

The same trend is expected for the population aged 15-24 years, who can continue the education in high schools, vocational schools, colleges and universities. Number of young people aged 15-24 years will be 2.2 million people in 2030 (both variants) and 1.4 million people in 2060.

\section{Discussion}

There is a disparity between the population of the older generation and the population of the younger generation. As stated in the findings, the age structure of the population has an ageing population, mainly due to falling birth rate, which resulted in absolute and relative reduction of the young population (0-14 years). Meanwhile, life expectancy increased in the share of elderly (65 and 
over). The older generation seems to be more than the younger generation and as time moves on, their population would increase further. From Table 2, it is evident that the population of the older generation increases every year. Life expectancy rate in Romania is high and most of the older generation live long. As at the time of the last census, the population between 0 and 14 years was $15 \%$, between 15 and 64 years was $70 \%$ and $15 \%$ over 65 years. Persons aged 85 years were $1.3 \%$. Keeping these percentages term requires questioning the sustainability of social security pensions and health, highlighting once again the need for measures to stimulate the birth and development of effective public policies in education, health and housing. As evident in previous literature, the older generation dominating the population of a country is not so significant since most of the older generation are either unproductive or may have long passed their childbearing stages (Cheah et al., 2016). Previous research has explained that the increase in the number of the elderly would mean more dependency rate, which will require the younger generation to work harder than usual in order to make provisions for the elderly who are dependent on them (Liang, Xu, Ma, Zhao \& Qin, 2017; Rusu, Zapata, Guedes \& Rigotti, 2020). This would end up slowing economic growth and put more pressure on natural resources and the climate (Santacreu, 2016; Stosic, Dermendzhieva \& Tomczyk, 2020).

The forecast for student population shows that the student population is likely to reduce as a result of the general reduction in population in Romania. According to the forecast, one key determinant of the reduction in the population of students would be the condition of external migration. When more people leave the country, lesser people would be available in the country, which would mean lesser students. On the other hand, if lesser people leave or there is no migration, more people would be available and more people would be in schools. The reason for advocating for a larger student population is as a result of the benefits that the country's economy, standard of living and other social conditions stands to gain. The more educated that people are, the more they take care of the environment (Baris, 2019). People are also more productive, creative and innovative when they are in their school ages and are active (Bernatonyte, Ciburiene, Simanaviciene \& Startiene, 2019; Santacreu, 2016). The more active people are, the more productive they are, hence, their involvement in improving economic growth (Rusu et al., 2020). Education and learning keep people active and innovative. It is evident that the elderly generation cannot be involved in learning actively in most cases. This is, therefore, the reason for the advocacy for younger people who can learn and work to improve quality of human life in general.

\section{Conclusion}

Romania experienced in recent decades significant changes in the population structure. Several factors have accounted to this. For instance, the changes in the demographic behaviour of couples to reproduce, increased mortality and emigration have caused the population to decline continuously. Romania's structure of age population reflects an ongoing process of demographic ageing, primarily due to declining birth rates leading to absolute and relative reduction of the young population (0-14 years) and growth of the elderly population of 65 years and over.

Until 2060, the population will have an overall downward trend and decreased share of school age group. This would mean more drastic measures need to be put in place to cater for the shortfall. As the EU recommendations explained, adult education should be encouraged in order to keep the ageing adults active. For the younger generation, smarter ways of learning that improves their capacities should be introduced in order to keep up to demand and also increase the quality of life of citizens. This would mean intensive training, workshops and advanced teaching methods among other productive learning methods. 


\section{References}

Acemoglu, D., Fergusson, L. \& Johnson, S. (2020). Population and conflict. The Review of Economic Studies, 87(4), 1565-1604. doi:10.1093/restud/rdz042

Ahmed, M. H., Djelti, S. \& Guellil, M. S. (2020). Migration, tourism, and the development of the home countries: evidence from Morocco. Global Journal of Business, Economics and Management: Current Issues, 10(1), 44-57. doi:10.18844/gjbem.v10i1.4704

Aksoy, A. \& Yilmaz, D. V. (2019). Assessment of male infertility. International Journal of Emerging Trends in Health Sciences, 3(1), 9-21. doi:10.18844/ijeths.v3i1.4093

Baris, S. (2019). Innovation and institutional quality: evidence from OECD countries. Global Journal of Business, Economics and Management: Current Issues, 9(3), 165-176. doi:10.18844/gjbem.v9i3.4364

Bernatonyte, D., Ciburiene, J., Simanaviciene, Z. \& Startiene, G. (2019). The impact of higher education on employment in the labour market: lithuanian case. Contemporary Educational Researches Journal, 9(1), 56-64. doi:10.18844/cerj.v9i1.3821

Cheah, I. K., Feng, L., Tang, R. M., Lim, K. H. \& Halliwell, B. (2016). Ergothioneine levels in an elderly population decrease with age and incidence of cognitive decline; a risk factor for neurodegeneration? Biochemical and Biophysical Research Communications, 478(1), 162-167. doi:10.1016/j.bbrc.2016.07.074

Coale, A. J. \& Hoover, E. M. (2015). Population growth and economic development. Princeton, NJ: Princeton University Press. doi:10.1515/9781400878598

Dax, T. \& Fischer, M. (2018). An alternative policy approach to rural development in regions facing population decline. European Planning Studies, 26(2), 297-315. doi:10.1080/09654313.2017.1361596

Dobos, C. (2020). Disciplining births: population research and politics in communist Romania. The History of the Family, 25(4), 599-626. https://doi.org/10.1080/1081602X.2020.1807384

Fihel, A. \& Okolski, M. (2019). Population decline in the post-communist countries of the European Union. Population Societies, 6, 1-4. Retrieved from https://www.cairn-int.info/revue-population-and-societies2019-6-page-1.htm

Garcia, M. M., Toledo, L. D. \& Rodriguez, M. L. H. (2020). Evaluation of inclusive measures against educational dropout. New Trends and Issues Proceedings on Humanities and Social Sciences, 7(3), 34-44. doi:10.18844/prosoc.v7i3.5230

Ioana, M. I., Anda, M. I., Cornelia, P. \& Mariana, C. R. (2015). School dropout-A social problem in Romania. Procedia-Social and Behavioral Sciences, 182, 623-628. doi:10.1016/j.sbspro.2015.04.795

ludici, A., Laura, P., Faccio, E. \& Neri, J. (2020). Application and coherence of the model of restorative justice in Europe. Global Journal of Sociology: Current Issues, 10(1), 01-08. doi:10.18844/gjs.v10i1.4750

Karaca, N. H., Uzun, H., Metin, S. \& Aral, N. (2020). Demographic factors associated with young children's motor creativity. Cypriot Journal of Educational Sciences, 15(5), 1307-1319. doi:10.18844/cjes.v15i5.5169

Kunimitsu, Y. (2017). Is Japanese economic growth possible under a decrease in population? Policy implication of dynamic spatial CGE model with endogenous growth mechanism. Retrieved from https://www.gtap.agecon.purdue.edu/resources/res_display.asp?RecordID=5275

Li, L., Lei, Y., Wu, S., He, C., Chen, J. \& Yan, D. (2017). Optimal scale of China's cities under the maximization of economic benefits and environmental benefits. Environmental Science and Pollution Research, 24(24), 19946-19954. doi:10.1007/s11356-017-9499-y

Liang, P., Xu, W., Ma, Y., Zhao, X. \& Qin, L. (2017). Increase of elderly population in the rainstorm hazard areas of China. International Journal of Environmental Research and Public Health, 14(9), 963. doi:10.3390/ijerph14090963

Luo, J., Zhang, X., Wu, Y., Shen, J., Shen, L. \& Xing, X. (2018). Urban land expansion and the floating population in China: for production or for living? Cities, 74, 219-228. doi:10.1016/j.cities.2017.12.007

Mehrolhassani, M. H., Mirzaei, S., Poorhoseini, S. S. \& Oroomiei, N. (2019). Finding the reasons of decrease in the rate of population growth in Iran using causal layered analysis (CLA) method. Medical Journal of the Islamic Republic of Iran, 33, 92. doi:10.34171\%2Fmjiri.33.92 
Mihaescu, C. (2020). Applications in demography and social statistics aplicatii in demografie si statistica sociala. Retrieved from https://insse.ro/cms/files/evenimente/RoCentenar/ROCentenar.pdf, Ed. Oscar Print, Bucuresti, 2004

Ministry of Education and Research. (2016). The strategy of education and vocational training in Romania for the period 2016-2020. Retrieved from https://edu.ro/strategia-educa\%C5\%A3iei-\%C5\%9Fi-form\%C4\%83riiprofesionale-din-rom\%C3\%A2nia Strategia educatiei si formarii profesionale din Romania pentru perioada 2016-2020

Mirela, C., Nicu, M. \& Oana-Valentina, C. (2016). Longer life with worsening pension system? Aging population impact on the pension system in two countries: Romania and Croatia. Economic and Social Development: Book of Proceedings, 28. Retrieved from https://search.proquest.com/openview/ 204e44dbab7730d5f1b1642fe015a845/1?pq-origsite=gscholar\&cbl=2033472

Mohammadi Laini, M. B. \& Gholami, S. (2015). Population decrease and its effect on the health of individual and family from the perspective of Islam. Journal of Religion and Health, 2(2), 62-73. Retrieved from http://jrh.mazums.ac.ir/article-1-125-en.html

National de Statistica. (2013). Proiectarea populatiei Romaniei la orizontul anilor 2060. Retrieved from https://insse.ro/cms/ro/tags/proiectarea-populatiei-romaniei-profil-teritorial-la-orizontul-anului-2060

National Institute of Statistics-Population Census. 1992-2011. Retrieved from https://insse.ro/cms/en

Park, K. (2020). Trend of income inequality in Asia and effects of education. Contemporary Educational Researches Journal, 10(2), 42-59. doi:10.18844/cerj.v10i2.4681

Rusu, A. B., Zapata, G. P., Guedes, G. R. \& Rigotti, J. I. R. (2020). Population ageing in Romania: a comparison of conventional-old-age dependency ratio (OADR) and prospective-old-age dependency ratio (POADR). Retrieved from https://sis.automacaodeeventos.com.br/2020/alap/sis/inscricao/resumos/0001/PPTeposter-trab-aceito-0286-2.PDF

Santacreu, A. M. (2016). Long-run economic effects of changes in the age dependency ratio. Economic Synopses, 17, 1-2. Retrieved from https://econpapers.repec.org/scripts/redir.pf?u=https\%3A\%2F\%2Fresearch. stlouisfed.org\%2Fpublications\%2Feconomic-synopses\%2F2016-09-02\%2Flong-run-economic-effects-ofchanges-in-the-age-dependency-ratio.pdf; $h=$ repec:fip:fedles:00071

Saricam, H. \& Ozbey, A. (2019). School anxiety and presenteeism in refugee children in Turkey. Global Journal of Guidance and Counseling in Schools: Current Perspectives, 9(2), 67-79. doi:10.18844/gjgc.v9i2.4427

Shopov, D. G., Mihaylova, V. K. \& Stoeva, T. R. (2016). Demography, birth rate and abortions in the district of plovdiv. Wschodnioeuropejskie Czasopismo Naukowe, 7(1), 109-114. Retrieved from https://www.elibrary.ru/item.asp?id=28152873

Stosic, L., Dermendzhieva, S. \& Tomczyk, L. (2020). Information and communication technologies as a source of education. World Journal on Educational Technology: Current Issues, 12(2), 128-135. doi:10.18844/wjet.v12i2.4815

Tannus, S. \& Dahan, M. H. (2019). Decrease in American birth rates makes it imperative for the United States to implement state mandated fertility coverage. Journal of Medical Economics, 22(3), 252-253. doi:10.1080/13696998.2018.1558866 